\title{
An Analysis of Students' Speaking Ability in Class Presentation during Covid-19 Pandemic at IAIN Padangsidimpuan
}

\author{
Ilham Hakim $^{1 *}$ and Zul Amri
}

\author{
${ }^{1}$ Universitas Negeri Padang, Padang, Indonesia, \\ ${ }^{2}$ Universitas Negeri Padang, Padang, Indonesia, \\ *Corresponding Author. E-mail: ilhamhakimnasution@gmail.com
}

\begin{abstract}
The Covid-19 pandemic has great challenges in people's life, including education. Physical distancing requires lecturers or teachers to do teaching and learning process through internet as the media. The use of e-learning is very important to support learning system by applying several platforms, such as YouTube, Zoom Meeting, Google Meet and others. This study aims to analyse students' speaking ability at the third year students of IAIN Padangsidimpuan on class presentation. This research is used the descriptive design. Students' class presentations by Zoom Meeting were recorded as data collection instrument. The subjects of the study were the third year students of IAIN Padangsidimpuan. The result of this study is the categories of the students' speaking ability in every aspects of speaking. To categorize the students speaking ability, the researcher adapted the rubric from Brown (2004) which categorizes students speaking on class presentation into pronunciation, vocabulary, grammar, fluency, and comprehension. Then, the students' average score is calculated and classified.
\end{abstract}

Keywords: Speaking, Ability, and Aspects

\section{INTRODUCTION}

Since the Corona Virus (Covid-19) pandemic struck, almost all countries have taken measures to reduce social and physical contact between individuals. This greatly affects various sectors of the economy, social and education. In the field of education, one of the government's policies is to make regulations in the form of WFH (Work from Home) to minimize the spread of the Covid-19. All teaching and learning processes become things that almost school are not usually done before.

Due to the limitations of direct communication, there are many internet media that can be used as an option for communicating. Video conferencing is one of the options for conducting face-to-face teaching and learning processes to face a virtual class. There are many platforms that can be used to conduct video conferences, free and paid, such as Zoom Meeting, Google Meet, GoTo Meeting, Team and others. The most popular use is zoom meeting, because the features and needs are more complete. With this video conference, the learning process can still be carried out, can be connected to each other both in terms of discussions, and conduct webinars. This is an option even though there will be many obstacles, but this can be used as a new experience that may continue to be used in the present or in the future.

Even in a pandemic situation of Covid-19, English still has an important role to learn because of several reasons; one of them is that it is so attached with the role of English as the international language for communication among nations that concern all parts of life. People may not meet in person in this pandemic, but communication is still ongoing does not rule out the possibility for anytime and anywhere. Consequently, English has a big influence on many aspects of global interaction, including education. Besides, English has become a language of science and technology. Therefore, English should be learned for communication, modernity, and also some others globally.

Meanwhile, communication is certainly related to the ability when giving and receiving information during communicating with anyone. In line with that, people need communication skills. According to Gilvon (1993) [1], skilled communicators are especially good at predicting what the listener or reader will know or think what is simple for them to deduce, what they are likely to deduce from context. So, the role of the speaking is very important to convey what things to say. According 
to Burns and Joyce, 1997 [2] ; Nunan, 2003 [3]; Brown, 2004[4]; Luoma, 2004 [5]; and Torky, 2006[6], speaking is an interactive way of constructing meaning by producing, developing and processing the information through verbal utterance. Moreover, Johnshon (1981) [7] \& Fulcher (2003) [8], speaking is a concept of the term "oral communication" means the verbal use of language to communicate with others. Others mean speaking activity involves two or more in which speakers and listeners do a contribution or have to respond each other to comprehend by both intention. Therefore, speaking can be concluded that could be one of the appropriate ways to share opinions, feelings, ideas, thoughts, messages, and information with others.

Regarding the teaching and learning process, speaking and listening are the common communications that occur in the classroom. In general, teachers deliver lessons by communicating directly to students orally. For this reason, speaking skills are very important for the teacher and students to have. Therefore, teachers must be able to direct students in honing their speaking skills with supportive classroom activities. One of the class activities that commonly conduct in the class is class presentation. This activity is able to describe students 'speaking ability beside as speaking forum for students.

The class presentation is mediation on how the students perform the materials explanation which given by the teacher or lecturers in the groups or pairs. Each students need to be able to perceive and understand the topic given in order in their presentation is not going out or confusing the audience. The term of presentation initial encounter the comprehensible input on spoken or written text. According to Penny in Himmah (2017) [10], she states that a group class presentation included various kinds of explanation, instructions, and also discussion of the new language item or task. So, in conducting the presentation the students must be understand the material as well such how to explain as presenter and for audience what to perceive based on the material explanation. It means also the presentation controlled through the topic discussion that given evaluate. So, to present the materials, the speaking of the students should be considered in the presentation in order to make audience understand the materials conveyed.

Afterward, in applying good speaking, students have to master several components of speaking such as vocabulary, grammar, pronunciation, fluency, accuracy, and also linguistic components. These components are very important because when the students listen to the presenter they can get the information correctly and understandable. As a description, speaking cannot be separated from pronunciation, since it is very important to know what exactly the speaker means, of course, it depends on the pronunciation. The case of wrong pronunciation also will present inappropriate meaning indeed the audience cannot catch the point beside bring to the unknown meaning or even to the new meaning that not related with the sentences. Besides, it is also very clear that fluency and accuracy are also important in speaking.

From the explanation above, several studies have been conducted related to the students speaking ability. Ilham, et. al., (2019) [11] describes the students' ability in speaking was on a good level. In line with the previous study, Rosmiaty, et. al., (2019) [12] reveal that students' speaking ability in speech class is dominant in the low score level. Besides, Rukmaryadi, et. al., (2020) [14] show that the English lecturer already applied the stages of teaching English through reading materials on certain topics but lacked oral activities in the first week of teaching but with more speaking in the second-week activities after the researcher holds a lengthy discussion. In the case of the participants' difficulties in speaking, it was noticeable that they had difficulties in grammar vocabulary, pronunciation, and fluency to some extent. Therefore, English lecturers when teaching need to provide students with more opportunities to practice speaking in order to improve their speaking ability.

Different to the previous study, this study present the analysis of the students' speaking ability on a presentation class recorded by Zoom Meeting at English departments of IAIN Padangsidimpuan in the process of online teaching and learning during Covid-19 pandemic. The objective of this research was to find out and describe students' speaking ability on class presentations by recording their performance by applying Zoom Meeting as media for conducting virtual class. The findings showed that the students' speaking is good and they are looking confidents to present the materials. It seems like the students do not affect by McDonough and Shaw (2002) [15], who argue that, speaking is often the skill upon which a person is judged at face value.

\section{METHOD}

This research was conducted at the English department of IAIN Padangsidimpuan. This research is used the descriptive design. According to Gay and Airasian (2000) [16] descriptive research is to find out the study statue of the research. The research purpose was to describe and analyze the students' speaking ability on class presentation during covid-19 pandemic. The subject of this research is the third-year students of English Department of IAIN Padangsidimpuan.. In this research, the researcher chooses 8 students as a participants in gathering the data namely $\mathrm{AA}, \mathrm{AB}, \mathrm{AC}$, $\mathrm{AD}, \mathrm{AE}, \mathrm{AF}, \mathrm{AG}$, and $\mathrm{AH}$.

In collecting the data, the researcher use documentation. The researcher records the students' performance in the class presentation by applying Zoom Meeting as media for virtual class. In this case, students will be a presenter of the material individually but work as a team in one topic discussion. Then, the researcher makes a description and conclusion based on the rubric of speaking by Brown (2004) [4] which are include five component of speaking to be scored; pronunciation, grammar, vocabulary, fluency, and comprehension. The researcher also used Harris (1974) [17] to determine the 
level of the ability. The techniques of data analysis are reduction, data display, and drawing conclusions.

\section{RESULT AND DISCUSSION}

Based on the data observation on students' class presentation by recording the Zoom Meeting class videos, the students are very disciplines and enthusiasm to learn. The following table was the result of speaking ability on class presentation of the third year students at English Department of IAIN Padangsidimpuan. As follows:

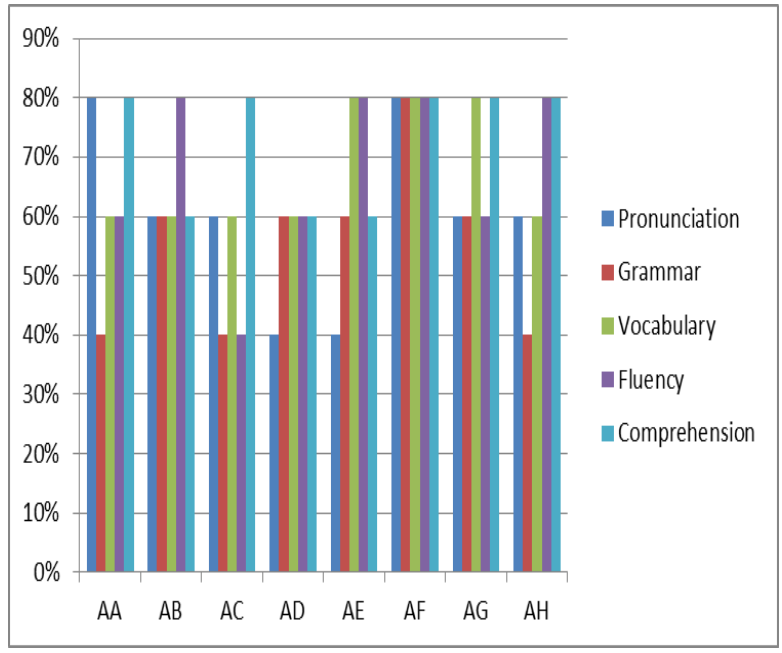

Figure 1. The result of speaking ability on class presentation of the third year students at English Department of IAIN Padangsidimpuan

Based on the information above, it was found that the eight students' speaking ability seem draw at the percentage achievements. The result of the rubric was described the students get speaking scored at the minimum score at least $40 \%$ and highest achieved $80 \%$. Based on the diagram above, the level of the students' speaking ability (Harris, 1974) as follows:

Table 1. The level of the students' speaking ability (Harris, 1974)

\begin{tabular}{|c|c|c|c|}
\hline $\begin{array}{c}\text { Test } \\
\text { Score }\end{array}$ & $\begin{array}{c}\text { Level of } \\
\text { Ability }\end{array}$ & Frequency & Percentage \\
\hline $80-100$ & Excellent & 1 & $12.5 \%$ \\
\hline $60-79$ & Good & 5 & $62.5 \%$ \\
\hline $50-59$ & Average & 2 & $25 \%$ \\
\hline $0-49$ & Poor & 0 & $0 \%$ \\
\hline
\end{tabular}

From the table of the level of the students' speaking above, it was found that the students are dominantly in the good level of the speaking ability. It is about $62.5 \%$ in the good level of ability which consists of 5 students. Besides that, there was 1 student who could achieve excellent level. The score also supported by the data that there were 2 students or $25 \%$ who could achieved the average level. Then there was no student in the position of the poor level of ability in speaking.

Based on the data from the participants, it can be seen that the students speaking ability is in the good level. This is still connected to the McDonough and Shaw (2002) [15] opinion about speaking is often the skill upon which a person is judged at face value. It is still find the students with problems in speaking at the zoom meeting class. But actually, in this case, the use of this platform seems the students unconsciously faced another students so that many students are looking enjoy while speaking to present material in class presentation. It means that students' speaking ability is affecting students confident while speaking at the class.

\section{CONCLUSION}

The global pandemic situation of COVID-19 teaches about how countries and world leaders can effectively maximize the use of technology as a medium for people to carry out their usual activities. This option is very good to keep a distance in accordance with health protocols to minimize the spread of the virus. As well as in education, the use of technology for online classes is a new experience. Based on the the research, result, and discussion of the study on an analysis of students' speaking ability on class presentation during covid-19 pandemic at IAIN Padangsidimpuan by zoom meeting Platform, the researcher conclude that students speaking ability is categorize in the good level. It means that the students are good in; pronunciation, grammar, vocabulary, fluency and comprehension. The students feel enjoyed while they present the material on class presentation. it seems like the students' self-confidents is built when they do not look at faced of the audience directly.

\section{ACKNOWLEDGMENT}

The researcher would like to thank to Allah SWT who gives his blessing until finished writing this paper. I also would like to thank to English Education Study Program, Universitas Negeri Padang. The warmest appreciation is given to my supervisor Dr. Zul Amri, M. Ed., for guiding me with good advices to finish this paper. The researcher realize this paper is far from being perfect, but hopefully this paper will be useful for the development of education especially for other researchers. Moreover, the researcher will be much appreciated to the readers for giving advices and critics.

\section{REFERENCES}

[1] Gilvon T. (1993). English grammar: A functionbased introduction. Amsterdam: John Benjamin Publishing.

[2] Burn, A., \&joyce, H. (1997). Focus On Speaking. Sydney: National Center for English Language Teaching and Research

[3] Nunan, D.(2003). Practical English language teaching. NY:McGraw-Hill

[4] Brown, H. D. (2004). Language Assessment: Principle and Classroom Practices. New York:Pearson/Longman

[5] Luoma, S. (2004). Assessing Speaking. Cambridge: Cambridge University Press. 
[6] Torky, S. A. E. F. (2006). The Effectiveness of a Task-Based Instruction Program in Developing the English Language Speaking Skills of Secondary Stage Students. Cairo: Ain Shams University https://files.eric.ed.gov/fulltext/ED523922.pdf

[7] Johnshon, K. M. (1981). Communication in the Classroom: Handbook for Teachers' Series. Longman.

[8] Fulcher, G. (2003). Testing Language Second Language Speaking. Longman.

[9] Brown, G., \& Yule, G. (2000). Teaching Spoken Language: Approach based on the Analysis of Conversational English. Cambridge: Cambridge University Press

[10] Himmah, N. (2017). Speaking problems faced by the EFL Learners in Individual Presentation. Thesis UIN Walisongo, Semarang.

http://eprints.walisongo.ac.id/9298/1/1403046005. pdf

[11] Ilham, Bafadal, M. F., \& Muslimin. (2019). The An Analysis of Students' Speaking Ability on Specific Purpose of Learning. Linguistics and English Language Teaching Journal, 7. https://core.ac.uk/display/287152526

[12] Rosmiaty, Ratnawati, \& Hasnilatuk. (2019). Students' Ability in Using Direct and Indirect Speech of English Department Students at Universitas Muslim Indonesia. ELT Worldwide, 6 (1), 73-82.

https://www.bing.com/search?form=MOZLBR\&p $\mathrm{c}=$ MOZD\&q=Students $\%$ E2\%80\%99+Ability+in+ Using+Direct+and+Indirect+Speech+of+Englis+ Department+Students+at+Universitas+Muslim+In donesia

[13] Savitri, D., \& Ardi, H. (2020). Analysis of Students' Speaking Ability in Video Project at STKIP MuhammadiyahMuaraBungo. Advances in Social Science, Education and Humanities Research, Proceedings of the Ninth International Conference on Language and Arts (ICLA 2020), 539, 47-50.

https://www.atlantis-press.com/proceedings/icla20/125954702

[14] Rukmaryadi, Zaim, M., \& Anwar, D. (2020). An Analysis of Non-English Department Students' Speaking Ability at Universitas Riau. Advances in Social Science, Education and Humanities Research, Proceedings of the 2nd International Conference Innovation in Education (ICoIE 2020), 504.

https://www.bing.com/search?form=MOZLBR\&p $\mathrm{c}=\mathrm{MOZD \& q}=$ An+Analysis + of + Non-

English+Department+Students\%E2\%80\%99+Spe aking+Ability+at+Universitas+Riau

[15] McDounough and Shaw. (2002) .Material and Method in ELT. London: Oxford University Press

[16] Gay, L.R \& Peter Airasian (2000). Educational Research (Competencies for Analysis and
Application) Six Edition. New Jersey: PrenticeHall.

[17] Harris, David. (1974). Testing English as a Second Language. New York: Mc. Graw. Hill Book Company 